\title{
Dampak pandemi coronavirus disease 2019 terhadap kualitas publikasi ilmiah
}

\author{
Yenny \\ Departemen Farmakologi dan Farmasi, Fakultas Kedokteran Univrsitas Trisakti, Indonesia \\ Email: yennyfarmako@trisakti.ac.id
}

Dunia medis belakangan ini digemparkan dengan dilaporkan adanya temuan kasus pneumonia tipe baru di kota Wuhan, Provinsi Hubei, Cina pada akhir Desember 2019.(1) Belakangan diketahui bahwa penyakit pneumonia tersebut disebabkan oleh patogen varian baru coronavirus yang disebut sebagai 2019-novel coronavirus (2019-nCoV)/severe acute respiratory syndrome coronavirus-2 (SARS-CoV-2) yang selanjutnya dikenal sebagai coronavirus disease 2019 (COVID-19) dan oleh the World Health Organization dinyatakan sebagai pandemi global pada tanggal 11 Maret 2020. ${ }^{(2)}$ Semenjak itu, para ilmuan mulai memfokuskan penelitian yang dilakukan pada topik yang berkaitan dengan COVID-19. Kondisi ini juga membawa dampak terdapatnya peningkatan volume publikasi artikel tentang COVID-19 yang sangat mencolok di mana dalam 6 bulan sejak terjadinya pandemi jumlah publikasi berbentuk riset, letters, reviews, notes, dan editorial yang berhubungan dengan COVID-19 dilaporkan berjumlah lebih dari 23.500 artikel. $^{(3)}$

Pada periode waktu 1 Januari - 1 Juni 2020, the Journal of the American Medical Association (JAMA) menerima lebih dari 11.000 manuskrip dalam sehari dibandingkan periode yang sama pada tahun 2019 sebanyak 4.000 manuskrip yang diterima dalam sehari. Hal ini menunjukkan terdapat peningkatan manuskrip yang disubmisi hampir 3 kali lipat dari biasanya pada masa pandemi COVID-19.(4) Guna mempercepat diseminasi hasil penelitian/informasi yang berkaitan dengan COVID-19 kepada masyakat di seluruh dunia, beberapa langkah telah ditempuh antar lain jurnaljurnal mempercepat waktu dari submisi hinggi publikasi, sementara para ilmuan mengunngah ribuan manuskrip ilmiah ke platform open access preprint servers, seperti bioRxiv, medRxix, arXiv, Research Square, Preprint.org, OSF, SSRN, dan
WHO bulletin tanpa melalui proses peer review oleh mitra bestari (peer reviewer) yang seyogyanya dilalui untuk mempertahankan kualitas sebuah artikel sebelum sebuah artikel dipublikasi. ${ }^{(5)}$

Peer review adalah sebuah proses fundamental di dalam bidang riset dan publikasi ilmiah di mana seseorang yang ahli di bidang topik tertentu diminta untuk mengevaluasi manuskrip yang dikirimkan (submit) oleh seseorang di bidang tersebut dan memberikan umpan balik berkaitan dengan kecocokan manuskrip ini untuk dipublikasi. ${ }^{(6)}$ Adanya pelaksanaan proses peer review maka akan dilakukan evaluasi dari laporan hasil penelitian yang tertulis di dalam manuskrip dalam kaitannya dengan kompetensi, signifikansi, dan originalitas data yang digunakan sebelum sebuah manuskrip dapat dipublikasikan. ${ }^{(7)}$ Proses peer review juga memiliki beberapa kekurangan yang berkaitan dengan proses peer review itu sendiri yaitu membutuhkan waktu yang relatif lebih lama, atau bila dilakukan oleh seseorang yang tidak menguasai topik yang sedang ditelaah, dan lainnya. ${ }^{(7)}$ Terlepas dari kekurangan yang ada, dengan dilaksanakannya proses peer review suatu manuskrip sebelum dipublikasi ikut memberikan kontribusi dalam mempertahankan kualitas publikasi.

Publikasi masif tanpa proses peer review yang ketat membawa dampak terbitnya beberapa artikel yang diragukan validitasnya bahkan diretraksi dari sebuah jurnal. Salah satu contoh, pada tanggal 25 September 2020 diterbitkan sebuah artikel di jurnal bereputasi PLoS One dengan judul Vitamin $D$ sufficiency, a serum 25-hydroxyvitamin D at least $30 \mathrm{ng} / \mathrm{mL}$ reduced risk for adverse clinical outcomes in patients with COVID-19 infection. ${ }^{(8)}$ Tidak sampai satu bulan setelah publikasi artikel Maghbooli et $a l .{ }^{(8)}$ pada tanggal 14 Oktober 2020 editor jurnal yang mempublikasi artikel tersebut menerbitkan 
artikel yang berisikan ekspresi keprihatinan akan validitas studi. Hal ini disebabkan dari judul dan simpulan artikel diperoleh kesan bahwa seolaholah terdapat hubungan antara kadar vitamin D dan luaran klinis infeksi COVID-19. Namun, pernyataan tersebut tidak didukung oleh data yang cukup (jumlah sampel, analisis statistik yang digunakan untuk menjawab tujuan penelitian, dan hanya $31.06 \%$ subjek yang dilakukan tes RT-PCR untuk konfirmasi diagnosis COVID-19), selain itu ditemukan adanya conflict of interest dari salah satu penulis artikel tersebut. ${ }^{(9)}$

Contoh lainnya dapat dilihat dari sebuah preprint paper yang berjudul Patterns of COVID-19 Mortality and Vitamin D: An Indonesian Study January 2020 yang penulisnya berasal dari Indonesia. ${ }^{(10)}$ Artikel ini dipertanyakan validitasnya di dalam letter to the editor dari British Journal of Nutrition ${ }^{(11)}$ terkait beberapa isu antara lain; penulis artikel tidak menyebutkan secara spesifik nama rumah sakit tempat studi dilakukan, ethical review board, maupun cara pengambilan data. Pada saat dilakukan konfirmasi, saat artikel ditulis hanya ada 2 kasus terkonfirmasi COVID-19 di rumah sakit umum daerah Sukamara. Dan saat pihak rumah sakit dihubungi, penulis artikel tersebut tidak dikenali karena tidak bekerja di rumah sakit tersebut. Saat ini tautan preprint di SSRN Electronic Journal yang menerbitkan artikel tersebut sudah tidak bisa di akses lagi. Namun, artikel yang pernah terbit ini sudah digunakan sebanyak $108.761 \mathrm{kali}$, diunduh sebanyak 17.361 kali, dan disebut di sosial media sebanyak 1.876 kali. ${ }^{(12)}$

Selain dua contoh di atas, saat ini terdapat beberapa artikel penelitian yang dipublikasi di jurnal medis bergengsi di dunia dan terindeks Scopus pada tanggal 4 Juni 2020 menarik artikelnya antara lain the New England Journal of Medicine ${ }^{(13)}$ dan the Lancet. ${ }^{(14)}$ Retraksi artikel yang sudah diterbitkan ini dilakukan karena penulisnya tidak bisa memberikan verifikasi untuk kesediaan akses data mentah dari penelitiannya dan tidak bisa menunjukkannya pada pihak ketiga untuk di audit. Beberapa contoh di atas memberikan sedikit gambaran fenomena yang cukup memprihatikan dan perlu mendapatkan perhatian khusus sebagai dampak pandemi COVID-19 dalam kualitas publikasi ilmiah.

Bila dilakukan penelusuran ke belakang, timbulnya fenomena ini sebagian berhubungan dengan kualitas dari penelitian yang dilakukan, sehingga ikut memberikan dampak pada luaran hasil penelitian, yaitu sebuah artikel ilmiah. Adanya prioritas utama untuk menyebarkan informasi yang berkaitan tentang COVID-19 melalui publikasi yang cepat mengakibatkan terdapat beberapa kelemahan dari peneltian yang dilakukan antara lain: kecilnya jumlah sampel penelitian yang dilakukan; kurangnya/tidak dilakukannya proses randomisasi dan ketersamaran (blinding); serta tidak tervalidasinya surrogate endpoint. ${ }^{(15)}$ Jumlah uji klinis tentang COVID-19 yang terdaftar pada ClinicalTrial.gov hanya $29.1 \%$, dan dari yang terdaftar tersebut hanya $29.3 \%$ uji klinis yang memenuhi "gold standard", yaitu menggunakan kontrol plasebo dan tersamar. ${ }^{(16)}$ Kelemahan yang terjadi ini khususnya terjadi di bagian metode dari suatu penelitian sudah diketahui akan memengaruhi validitas dari hasil suatu penelitian.

Tingginya tuntutan akan cepatnya diseminasi informasi tentang COVID-19 kepada pembaca, menyebabkan jurnal bereputasi melakukan telaah dipercepat (expedited review) terhadap suatu artikel dan sekaligus mendorong publikasi dalam bentuk preprint. ${ }^{(17)}$ Sebagai gambaran, pada masa pandemi COVID-19 ini median waktu suatu artikel jurnal mulai dari submisi hingga diterima membutuhkan waktu yang sangat singkat yaitu hanya dalam waktu 6 hari, sementara dibutuhkan waktu yang lebih lama yaitu 93 hari untuk menerbitkan artikel nonCOVID-19 pada jurnal yang sama. ${ }^{(18)}$

Terdapat penelitian yang melihat kualitas publikasi artikel tentang COVID-19 dibandingkan dengan publikasi non-COVID-19 menggunakan data yang diperoleh dari database PubMed dari 12 Maret hingga 12 April 2020. ${ }^{(19)}$ Hasil penelitian ini menunjukkan publikasi COVID-19 lebih mungkin memiliki tingkat evidence 186 kali lebih rendah secara bermakna dibandingkan publikasi nonCOVID-19. Rendahnya kualitas hasil publikasi COVID-19 salah satunya bisa disebabkan karena terkesampingkannya proses evaluasi review ilmiah oleh mitra bestari yang tentunya dapat memengaruhi kualitas dari artikel yang dipublikasi dan memberikan asumsi yang salah karena berasal dari evidence yang belum diverifikasi. ${ }^{(20)}$ Cepatnya diseminasi hasil studi yang berasal dari studi-studi dengan level kualitas evidence yang rendah dapat 
menimbulkan informasi yang salah, memengaruhi opini publik, memengaruhi tindakan yang akan dilakukan pemerintah, memengaruhi praktik klinis yang tentunya berpotensi menimbulkan bahaya bila mengunakan informasi yang tidak valid tersebut. ${ }^{(21)}$

Pada akhirnya disadari bahwa tuntutan publikasi yang cepat pada masa pandemi COVID-19 bertujuan untuk mendiseminasikan evidence terbaru kepada pembaca sangat penting. Namun, mempertahankan validitas dan kualitas ilmiah dari artikel yang akan dipublikasi juga tidak kalah pentingnya. Adanya pandemi COVID-19 menyebabkan perlunya pembaharuan sistem proses peer review agar dapat dilakukan dalam waktu yang relatif lebih singkat namun tetap mempertahankan validitas dan kualitas artikel yang diterbitkan. Proses peer review umumnya membutuhkan waktu beberapa minggu hingga beberapa bulan yang menjadi salah satu hambatan pada masa pandemi ini di mana diseminasi informasi dibutukan dengan cepat. ${ }^{(22)}$ Salah satu cara yang dapat ditempuh untuk mempersingkat waktu peer review pada masa pandemi ini dapat dilakukan dengan melakukan pertemuan dengan penulis artikel dengan memanfaatkan berbagai platform video conference, seperti Skype, Zoom Meeting, Teams, Google Meet, Google Duo, dan Cisco Webex dan aplikasi lainnya untuk mengkonfirmasi temuan pada manuskrip bila dibutuhkan klarifikasi sebelum dipublikasi. Selain itu, artikel yang dipublikasi sebaiknya hanya artikel yang sudah melalui tahapan review yang adekuat oleh peer reviewer yang kompeten di bidangnya agar dapat mendeteksi laporan artikel yang tidak adekuat dengan cepat. ${ }^{(23)}$ Berbagai daftar cek untuk melaporkan suatu studi, seperti halnya daftar cek untuk melaporkan studi-studi yang bersifat observasional dari STROBE (Strengthening the reporting of observational studies in epidemiology) ${ }^{(24)}$ dan daftar cek untuk melaporkan artikel-artikel yang mengunakan desain (RCT) dari CONSORT (Consolidated Standard of Reporting Trial) ${ }^{(25)}$ dapat digunakan sebagai panduan bagi penulis saat menuliskan manuskrip yang akan dipublikasi dan bagi mitra bestari dalam melaksanakan proses peer review. Bila ditemukan adanya pelanggaran etika publikasi, maka para editor dan penerbit jurnal dapat menyikapi kasus tersebut dengan menggunakan panduan yang dikeluarkan oleh the
Committee on Publication Ethics (COPE) yang telah menjadi acuan oleh pengelola jurnal di dunia selama ini. ${ }^{(26)}$ Informasi yang bersumber dari server preprint berasal dari manuskrip yang belum melalui proses peer review, seperti yang tertulis di manuskripnya sehingga masih memungkinkan untuk mengalami perubahan dan kadang tidak selalu diperbaharui di server preprint. Pada masa pandemi lebih disarankan para pembaca untuk mencari informasi tentang COVID-19 melalui artikel ilmiah yang sudah melalui tahapan proses peer review. Perlu dipahami proses peer review suatu artikel hanya salah satu metode yang dapat ditempuh oleh pengelola jurnal untuk dapat mempertahankan kualitas sebuah artikel yang dipublikasi. Agar dapat memberikan informasi yang akurat dan menghindari misinformasi maka diperlukan kerja sama antara pihak editor, penerbit, server preprint, penulis, dan media untuk dapat menyampaikan informasi ilmiah khususnya tentang COVID-19 kepada masyarakat dengan menggunakan sumber data yang valid. ${ }^{(27)}$

\section{REFERENSI}

1. Zhu N, Zhang D, Wang W, et al. A Novel Coronavirus from Patients with Pneumonia in China, 2019. N Engl J Med. 2020;382(8):727-733. doi: 10.1056/NEJMoa2001017

2. World Health Organization. WHO DirectorGeneral's opening remarks at the media briefing on COVID19 - 11 March 2020 [Internet]. World Health Organization; 2020. Available from: https:// www.who.int/director-general/speeches/detail/ who-director-general-s-opening-remarks-at-themedia-briefing-on-covid-19---11-march-2020

3. Nature Index. COVID-19 research update: How many pandemic papers have been published? A briefing on developments in coronavirus research publishing [Internet]. Nature Index; 2020 Aug 28 [cited $2021 \mathrm{Feb} 23$ ]. Available from: https://www. natureindex.com/news-blog/how-coronavirus-ischanging-research-practices-and-publishing

4. Bauchner H, Fontanarosa PB, Golub RM. Editorial Evaluation and Peer Review During a Pandemic: How Journals Maintain Standards. JAMA. 2020;324:453-4. doi:10.1001/jama.2020.11764

5. ASAPbio. Preprints and Rapid Communication of COVID-19 research Internet]. San Francisco (CA): ASAPbio; c2021 [cited 2021 Feb 23]. Available from: https://asapbio.org/preprints-and-covid-19

6. Wierzbinski-Cross H. Peer Review. J Nurses Prof Dev. 2017;33:102-4. doi: 10.1097/ NND.0000000000000327.

7. Manchikanti L, Kaye AD, Boswell MV, et al. Medical journal peer review: process and bias. Pain Physician. 2015;18:E1-14.

8. Maghbooli Z, Sahraian MA, Ebrahimi M, et al. Vitamin D sufficiency, a serum 25-hydroxyvitamin $\mathrm{D}$ at least $30 \mathrm{ng} / \mathrm{mL}$ reduced risk for adverse clinical outcomes in patients with COVID-19 infection. 
PLoS ONE 2020; 15(9): e0239799. doi:10.1371/ journal.pone.0239799

9. The PLOS ONE Editors. Expression of Concern: Vitamin D sufficiency, a serum 25-hydroxyvitamin $\mathrm{D}$ at least $30 \mathrm{ng} / \mathrm{mL}$ reduced risk for adverse clinical outcomes in patients with COVID-19 infection. PLoS ONE 2020;15(10): e0240965. doi: 10.1371/journal.pone.0240965.

10. Raharusuna $\mathrm{P}$, Priambada S, Budiarti C, et al. Patterns of COVID-19 Mortality and Vitamin D: An Indonesian Study January 2020 [Internet]. SSRN Electron J; [cited 2021 Feb 7]. doi: 10.2139/ ssrn.3585561. Available from: https://scholar. google.co.id/scholar?cluster $=1010095645010335$ $7831 \& \mathrm{hl}=$ en\&as $\mathrm{sdt}=0,5 \&$ as vis $=1$

11. Henrina J, Lim MA, Pranata R. COVID-19 and misinformation: how an infodemic fuelled the prominence of vitamin D. Br J Nutr. 2021;125:35960. doi: 10.1017/S0007114520002950.

12. PlumX Metrics. Patterns of COVID-19 mortality and vitamin D: an Indonesian study [Internet]. PlumX Metrics; 2020 [cited 2021 Feb 21] Available from: https://plu.mx/ssrn/a/?ssrn_id=3585561

13. Mehra MR, Desai SS, Kuy SR, et al. Retraction: Cardiovascular Disease, Drug Therapy, and Mortality in Covid-19. N Engl J Med. DOI: 10.1056/NEJMoa2007621. N Engl J Med 2020; 382:2582. doi: 10.1056/NEJMc2021225

14. Mehra MR, Ruschitzka F, Patel AN. RetractionHydroxychloroquine or chloroquine with or without a macrolide for treatment of COVID-19: a multinational registry analysis. Lancet 2020;395:1820. doi: 10.1016/S01406736(20)31324-6

15. Kim AHJ, Sparks JA, Liew JW, et al. A Rush to Judgment? Rapid Reporting and Dissemination of Results and Its Consequences Regarding the Use of Hydroxychloroquine for COVID-19. Ann Intern Med. 2020;172:819-21. doi: 10.7326/M20-1223.

16. Pundi K, Perino AC, Harrington RA, et al. Characteristics and Strength of Evidence of COVID-19 Studies Registered on ClinicalTrials. gov. JAMA Intern Med. 2020;180:1398-1400. doi:10.1001/jamainternmed.2020.2904

17. Rubin EJ, Baden LR, Morrissey S, et al. Medical Journals and the 2019-nCoV Outbreak. N Engl J Med. 2020;382(9):866. doi: 10.1056/ NEJMe2001329.

18. Palayew A, Norgaard O, Safreed-Harmon K. et al. Pandemic publishing poses a new COVID-19 challenge. Nat Hum Behav .2020; 4: 666-9. doi: 10.1038/s41562-020-0911-0

19. Zdravkovic M, Berger-Estilita J, Zdravkovic B, et al. Scientific quality of COVID-19 and SARS CoV-2 publications in the highest impact medical journals during the early phase of the pandemic: A case control study. PLoS One. 2020;15(11):e0241826. doi: 10.1371/journal. pone. 0241826.

20. Steinberg I. Coronavirus research done too fast is testing publishing safeguards, bad science is getting through [Internet]. The Conversation; 2020 [cited 2021 Feb 21]. Available from: http:// theconversation.com/coronavirus-research-donetoo-fast-is-testing-publishing-safeguards-badscience-is-getting-through-134653

21. Kim AHJ, Sparks JA, Liew JW, et al. A rush to judgment? rapid reporting and dissemination of results and its consequences regarding the use of hydroxychloroquine for COVID-19. Ann Intern
Med. 2020;172:819-21. doi:10.7326/M20-1223

22. Tennant JP, Ross-Hellauer T. The limitations to our understanding of peer review. Res Integr Peer Rev. 2020;30;5:6. doi: 10.1186/s41073-020-00092-1.

23. Chauvin A, Ravaud P, Moher D, et al. Accuracy in detecting inadequate research reporting by early career peer reviewers using an online CONSORTbased peer-review tool (COBPeer) versus the usual peer-review process: a cross-sectional diagnostic study. BMC Med. 2019;17(1):205. doi: 10.1186/ s12916-019-1436-0.

24. von Elm E, Altman DG, Egger M, et al. The Strengthening the Reporting of Observational Studies in Epidemiology (STROBE) Statement: guidelines for reporting observational studies. Int J Surg. 2014;12(12):1495-9. doi: 10.1016/j. ijsu.2014.07.013

25. CONSORT transparent reporting of trials. Available from: http://www.consort-statement.org/

26. COPE (Committee on Publication Ethic). Promoting integrity in scholarly research and its publication. Available from : https:// publicationethics.org/guidance/Guidelines

27. Bagdasarian N, Cross GB, Fisher D. Rapid publications risk the integrity of science in the era of COVID-19. BMC Med. 2020;18: 192. doi: 10.1186/s12916-020-01650-6 